症 例

消化管穿孔として開腹術を行った腸管囊腫様気腫症の 1 例 屋島総合病院外科, 香川大学病理部*

$\begin{array}{llllllll}\text { 池 } & \text { 田 } & \text { 宝 } & \text { 过 } & \text { 和 宏 三 谷 英 信 } \\ \text { 斉藤 } & \text { 誠 } & \text { 安 } & \text { 藤 } & \text { 隆 史 羽 場 礼 次* }\end{array}$

腸管震腫様気腫症は，確定診断が出来れば重篤な臨床症状がない限り，保存的治療が 可能な疾患である.今回われわれは，消化管穿孔として開腹術を行った腸管囊腫様気腫 症の 1 例を経験したので報告する。症例は 80 歳, 女性. 右下腹部痛を主訴に当院内科を 受診した. 胸部・腹部X線写真では異常所見を認めなかった. 腹部 CT, 超音波検査にて, 肝表面に腹腔内遊離ガス像と，盲腸から上行結腸にかけて腸管壁の肥厚を認めた．以上 から，結腸礊室穿孔または虫垂穿孔による腹膜炎を疑い，緊急開腹手術を行った，消化 管に明らかな穿孔部は認めなかったが, 回腸末端から約 $90 \mathrm{~cm}$ 口側の回腸槳膜下および 腸間膜に, 多数の気腫性変化と散在する粘膜下腫湯様の硬結を触知した。手術は約 $25 \mathrm{~cm}$ の回腸を切除した，病理組織学的検査では, 粘膜下層に襄胞状病変を認め, 腸管囊胞様 気腫症と診断した。術後経過は良好で, 現在, 術後約 8 カ月を経過したが, 再発は認め ていない.

索引用語：腸管襄腫様気腫症, 消化管穿孔

\section{緒 言}

腸管襄腫様気腫症 (pneumatosis cystoides intestinalis, PCI) は確定診断が出来れば保存的に治療が可 能な疾患であるが, 臨床的に遭遇する機会は稀である。 今回われわれは，消化管穿孔として開腹術を行った腸 管䨢腫様気腫症の 1 例を経験したので若干の文献的考 察を加え報告する。

\section{症 例}

症例：80歳, 女性.

主訴：右下腹部痛.

家族歴：特記すべきことなし。

既往歴：平成 4 年から気管支拡張症のため当院内科 通院中.

現病歴：平成15年 9 月 9 日, 早朝から右下腹部痛が 出現したため, 当院内科を受診した.

入院時現症: 身長 $150 \mathrm{~cm}$, 体重 $40 \mathrm{~kg}$. 体温 $37.6^{\circ} \mathrm{C}$. 結膜に䀜血, 黄疸は認めなかった，右下腹部に軽度の 圧痛を認めたが, 腹部は全体に軟で筋性防御などの腹

2004 年 1 月 9 日受付 2004 年 6 月 3 日採用 〈所属施設住所〉

干761-0186 高松市屋島西町1857- 1

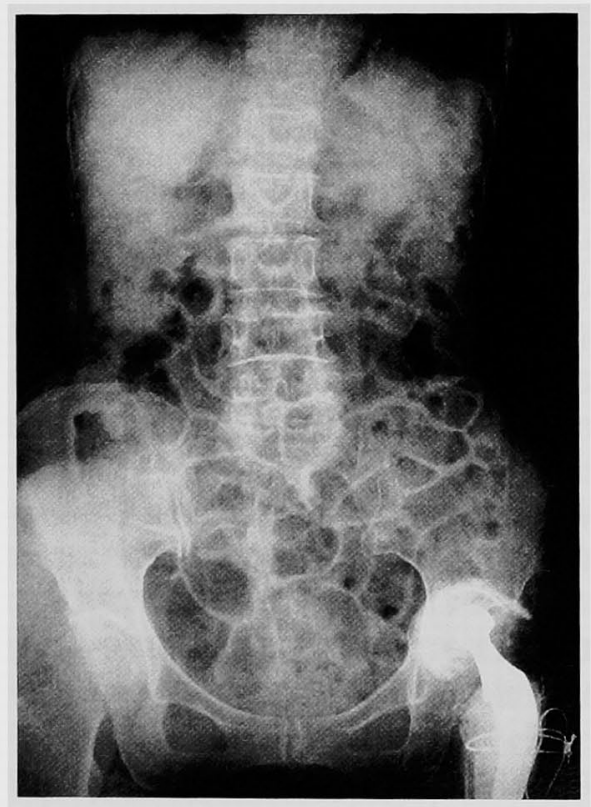

図 1 腹部単純 $\mathbf{X}$ 線写真 : 腸管の拡張所見, 腹腔 内遊離ガスなどの異常所見は認めなかった。 


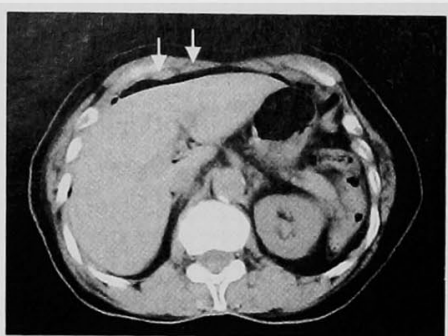

a

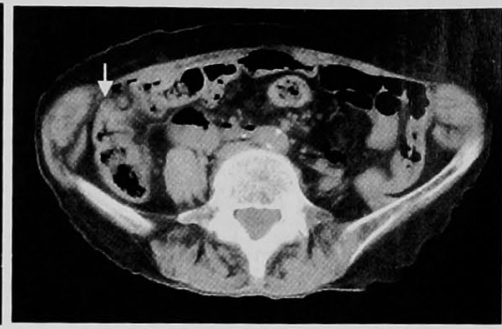

b

図 2 腹部 CT 所見：a）肝表面に腹腔内遊離ガスの散在を認めた，b)盲腸から 上行結腸にかけて軽度の壁肥厚を認めた。

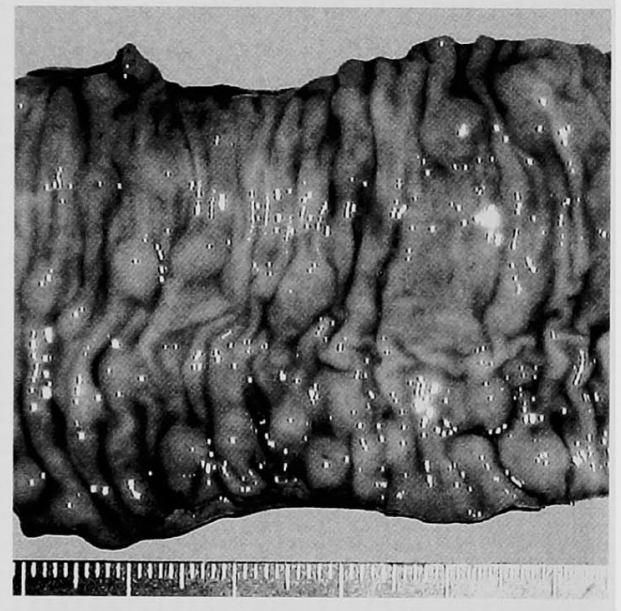

図 3 切除標本肉眼的所見 : 軽度弾性硬, 大小不同 性の粘膜下腫瘍様隆起性病変の散在を認めた。

膜刺激症状は認めなかった。

入院時検查所見 : WBC $10,600 / \mu \mathrm{l}, \mathrm{CRP} 1.4 \mathrm{mg} / \mathrm{ml}$ と炎症所見の軽度上昇を認めた。その他生化学検査に 異常所見は認めなかった。

胸部単純 X 線写真：両肺野に気管支拡張症に伴う 浸潤影の散在を認めた。横隔膜下に遊離ガス像は認め なかった。

腹部単純 $\mathrm{X}$ 線写真 : 下腹部を中心にガス像が多い が腸管の拡張所見はなく, 腹腔内遊離ガスも認めなか った (図 1 ).

腹部超音波所見 : 腹腔内遊離ガスと盲腸から上行結 腸にかけての腸管壁の肥厚を認めた。

腹部 CT 所見：肝表面に腹腔内遊離ガスの散在を認 めた(図 2 a)。また，盲腸から上行結腸にかけて軽度 の壁肥厚を認めた（図 2 b ).
上腹部内視鏡検査所見：胃，十二指腸に腫場や潰場 性病変は認めなかった。

以上から，盲腸・上行結腸の秘室穿孔あるいは虫垂 穿孔を考え，受診当日緊急開腹手術を行った。

手術所見：腹挖内に少量の漿液性腹水が貯留してい たが，消化管内容物の散布は認めなかった，胃から直 腸まで詳細に観察を行ったが，明らかな穿孔部は認め なかった。しかし，回腸末端から約 $90 \mathrm{~cm}$ 口側の回腸獎 膜下および腸間膜に多数の気腫性変化を認めた.また, 同部に一致して散在する粘膜下腫湟様の硬結を触知し た．以上の所見から，腸間膜側への回腸穿孔の可能性 も否定できないこと，同部が今回の腹痛，腹腔内遊離 ガスの要因と考え, 約 $25 \mathrm{~cm}$ の回腸部分切除術を行っ た.

切除標本肉眼的所見：獎膜面には大小不同, 軽度弾 性硬の粘膜下腫湯様隆起性病変の散在を認めた。粘膜 面に潰黇性病変および穿孔は認めなかった（図 3 ).

病理組織学的所見: 肉眼的隆起性病変に一致して, 粘膜下層に蘘腫状変化を認めた(図 $4 \mathrm{a}, \mathrm{b}$ )。明らか な腫瘍性病変は認めず,腸管䑴腫様気腫症と診断した。

術後経過：合併症なく経過し, 術後第21病日目に退 院した。現在術後約 8 カ月を経過したが, 再発は認め ていない.

\section{考 察}

腸管蓓腫様気腫症は消化管の粘膜下や漿膜下に多発 性の含気性䧶腫が存在する疾患であり ${ }^{11}$ ，現在までに 500例以上の報告があるが臨床的には稀な疾患である. その発生機序は明らかではないが, 細菌説2), 機械説 ${ }^{3)}$, 肺原説(), 化学説可などが提唱されている.つまり, 細 菌説では腸管壁にガスを生成する弱毒性の非病原性細 菌が進入して起こり, 機械説では腸管狭窄のために腸 管内圧元進をきたして腸管内ガスが粘膜の微細な損傷 


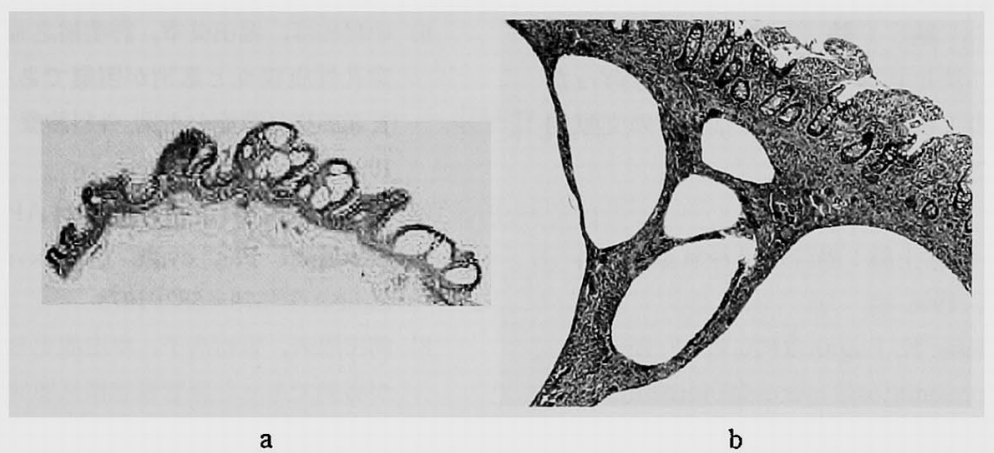

図 4 病理組織学的所見 : 肉眼的隆起性病変に一致して, 粘膜下層に罼腫状変化 を認めた（a：HE染色ルーペ像，b；HE染色 $\times 4 ）$.

ないし潰瘍周辺より腸管壁内に進入して起こるとされ る.また, 肺原説では喘息や慢性気管支炎などの閉塞 性肺疾患に合併し，肺胞破裂により流出した気体が綐 隔気腫となり後腹膜経路で血管壁に沿って腸管壁に進 入することにより発症し, 化学説ではトリクロールエ チレンに慢性的に暴露されるために発症するとされ， 気腫内にトリクロールエチレンが検出される. 自験例 においては, 術中採集した腹水からガス産性菌は検出 されず, 術前検査, 手術所見でも腸管狭窄の所見はな く,トリクロールエチレンの暴露歴もないことから細 菌説, 機械説, 化学説は否定的である.したがって, 自験例では胸部 X線写真, 腹部 CT で縌隔気腫および 後腹膜気腫は認めていないが，既往歴に気管支拡張症 があることから肺原説が最も有力と考えられる。

本症の診断は, 腹部単純 X 線写真, 腹部 CT 検査, 注腸検査, 下部消化管内視鏡検査などで診断可能であ るとされる ${ }^{1}$. 腹部単純 X線写真では, 腸管壁に沿った 多発性亯腫状気腫が特徵的である. 腹部 CT では腸管 壁内気腫を認める。結腸例では, 注腸検查で多数の隆 起性病変の集簇を認め, 下部消化管内視鏡検查では大 小さまざまな粘膜下腫瑒様隆起の多発が特徵的であ る. 自験例では, 術前の腹部単純 X線写真, $\mathrm{CT}$ で多発 性袈腫状気腫といったような特徴的な所見は確認でき ず, 確定診断には至らなかった。

本症の臨床症状としては, 腹痛, 腹部膨満感, 嘔吐 など不定愁訴が多く, 腹痛を訴える場合でも, 筋性防 御など腹膜刺激症状を呈することは稀である6).

本症の治療法に関して, 一般的に, 通過障害, 大量 出血, 壊死など重篤な合併症がない限り外科的治療の 適応とならず，保存的治療を行うべきとされている. 最近では，高濃度酸素吸入が有効であると多数報告さ
れており71-10)，治療の第一選択となっている，自験例 で, 主訴が右下腹部痛であり, 腹部超音波・CT で盲 腸および上行結腸の壁肥厚を認め,さらに腹腔内遊離 ガス像を認めたことから，結腸憩室穿孔や虫垂穿孔を 考え緊急開腹手術を行った。これは，臨床的には腹膜 刺激症状はなく，炎症所見は軽度であったが画像上腹 腔内遊離ガスを認めており，高路者でもあることから ショックを旺する前に手術が必要であると判断したた めである.今回われわれが検索した範囲内（医学中央 雑誌1994年〜2004年) では，本症として61件，計68例 の報告があった.この内，43例は術前に本症と診断し 保存的治療が行われているが，25例に対しては緊急手 術が行われ, 消化管穿孔, 腸管壊死など, 重篤な合併 症を伴うものは13例であった。自験例と同様に消化管 穿孔として緊急手術を行い, 術中および切除標本所見 から本症と診断した症例は12例認めており, 手術適応 の判断が難しい症例も混在することが示唆される.久 松ら ${ }^{11}$ は, 消化管穿孔を疑った症例に対し, 術中腹腔鏡 所見から本症と診断，保存的に治療を行い，良好な結 果を得たと報告している。このことから腫腔鏡は, 術 前に本症として確定診断の出来ない場合の有用な診断 方法であると考えられる。

本症として確定診断が行え，かつ全身状態が安定し ていれば，保存的に治療可能な疾患である，腸管壁の 気腫像などの典型的な画像所見を認めない場合でも， 腹腔内遊離ガス像を認める疾患として鑑別を考慮する 必要がある.しかし, 重篤な合併症と併存している可 能性もあることから, 手術適応については, 画像所見, 臨床症状などを踏まえ, 十分な考慮が必要であると考 えられる。 


\section{結語}

今回われわれは，消化管穿孔として開腹術を行った 腸管薄腫様気腫症の 1 例を経験したので若干の文献的 考察を加え報告した。

\section{文献}

1）高田秀穗，日置絋士郎：腸管裹腫様気腫. 消外 $19: 844-846,1996$

2) Gillon J, Tadesse K, Logan RFA, et al : Breath hydrogen in pneumatosis cystoides intestinalis. Gut 20:1008-1011, 1979

3) Meyers MA, Ghahremani GG, Clements JL Jr, et al: Pneumatosis intestinalis. Gastrointest Radiol 2:91-105, 1977

4) Keyting WS, McCarver RR, Kovarik JL, et al : Pneumatosis intestinalis: A new concept. Radiology $76: 733-741,1961$

5）山口孝太朗, 白井忠, 上野一书他：Trichlor oethylene 使用の職業歴を有する大腸腸管教腫様 気腫の 2 例。信州医誌 $32 ： 579-587,1984$
6）中村和产，堀田美幸，許斐裕之他：気腹を合併し 穿孔性腹膜炎と鑑別が困難であった S 状結腸腸 管霍腫様気腫症の 1 例.外科䛦療 $2: 213-216$, 1993

7) Forgacs $P$, Wright $P$, Wyatt AP : Treatment of intestinal gas cysts by oxygen breathing. Lancet $1: 579-582,1973$

8）前田陽夫, 吉村浩子, 牟田龍史他：高圧酸素療法 が有効であった腸管整胞様気庫症の 1 例. 消内視 鏡 $11: 338-341 ， 1999$

9）栗原祥佳, 大越裕章, 日高 徹他：鼻空力ニュー レによる酸菜療法が有刘であった腸管藮胞様気嗹 01例. 広島医 54:774-777，2001

10）中村研二, 朝長道生，梶山捁史他：小腸，大腸及 び胃に skipしてみられた腸管莡腫様気腫症の】 例. 日消病会誌 $98: 948-952,2001$

11）久松 貴，七島篤志，泉川公一他：腹腔鏡が猃断 および治療に有効であった腸管䉴胞様気腫症のI 例，日消外会誌 $37: 1587-1592 ， 2003$

\title{
A CASE OF PNEUMATOSIS CYSTOIDES INTESTINALIS PERFORMED LAPAROTOMY WITH A DIAGNOSIS OF INTESTNAL PERFORATION
}

\author{
Hirokuni IKEDA, Kazuhiro TSUJI, Hidenobu MITANI, \\ Makoto SAITO, Takashi ANDO and Reiji HABA* \\ Department of Surgery, Yashima General Hospital \\ ${ }^{*}$ Diagnostic Pathology, Faculty of Medicine, Kagawa University
}

Pneumatodes cystoides intestinalis is a disease that can be treated conservatively, if the correct diagnosis is made as far as serious clinical manifestations are absent. We report a case of pneumatosis cystoides intestinalis performed laparotomy with a diagnosis of intestinal perforation.

An 80-year-old woman was seen at the department of internal medicine in our hospital because of right lower abdominal pain. No abnormalities were shown on chest and abdominal $x$-ray films. Abdominal CT and ultrasonography revealed intraabdominal free air on the surface of the liver and thickening of the wall of the gut covering from the cecum to ascending colon. From these findings, peritonitis due to perforation of either colonic diverticulum or the appendix was suspected, and an emergency laparotomy was performed at the department. No recognizable perforation was seen in the gut, but numerous emphysematous changes and scattered elastic-hard indurations like submucosal tumors were palpated in the subserosal structure and mesentery of the ileum about $90 \mathrm{~cm}$ proximal to the terminal ileum. At surgery, the ileum by about $25 \mathrm{~cm}$ was resected. Histopathologically these cystic lesions were identified to be submucosal, and pneumatosis cystoides intestinalis was diagnosed. The patient's postoperative course was uneventful. There have been no signs of recurrence as of 8 months after the operation. 